\title{
Natural history of Oxyrrbexis zephyrus sp.n. (Hymenoptera: Ichneumonidae), a parasitoid of Enoplognatha serratosignata (Araneae: Theridiidae), with notes on taxonomy and other host species of Oxyrrbexis
}

\section{Биология Oxyrrbexis zepbyrus sp.n. (Hymenoptera: Ichneumonidae), паразитоида Enoplognatha serratosignata (Araneae: Theridiidae), с заметками по таксономии и Аругим хозяевам Oxyrrbexis}

\author{
Niclas R. Fritzén ${ }^{1,2} \&$ Arne Fjellberg ${ }^{3}$ \\ Н. Фритзен ${ }^{1,2}$, А. Фйемлберг ${ }^{3}$
}

\footnotetext{
${ }^{1}$ Zoological Museum, University of Turku, FI-20014 Turku, Finland.

${ }^{2}$ Klemetsögatan 7B7, FI-65100 Vasa, Finland. E-mail: nrfritzen@gmail.com

${ }^{3}$ Mågerøveien 168, N-3145 Tjöme, Norway. E-mail: arnecoll@gmail.com
}

KEY WORDS: Norway, Polysphincta genus-group, Chablisea, new host records, spider, Steatoda, Alaska, cocoon.

КЛЮЧЕВЫЕ СЛОВА: Аляска, Норвегия, группа видов Polysphincta, Chablisea, новый хозяин, паук, Steatoda, кокон.

ABSTRACT. Oxyrrhexis zephyrus sp.n., belonging to the Polysphincta genus-group, is described. Like all other species of this group, the new species is a koinobiont ectoparasitoid of spiders. It has been reared from the ground-living theridiid Enoplognatha serratosignata (L. Koch, 1879) in Norway. Chablisea shaanxiensis (Liu, He et Chen, 2009) comb.n. is proposed, ex Oxyrrhexis; thus Oxyrrhexis still comprises only four known species worldwide, but now with two species in the West Palaearctic. Oxyrrhexis carbonator (Gravenhorst, 1807), as its subspecies texana (Cresson, 1870), is reported as new to the state of Alaska. Steatoda bipunctata (Linnaeus, 1758) is reported as the host of $O$. carbonator in Europe and, based on a large reared material from Finland, Sweden and Norway, this seems to be the only host of the nominate subspecies, at least in northern Europe. Parasitised hosts and the cocoons of the new species and $O$. carbonator are figured. The host record for the new species together with the data presented and discussed in this paper strongly support the hypothesis of Oxyrrhexis being a genus specialised in attacking the spider family Theridiidae. Literature records of other spider families and non-spiders as hosts for $O$. carbonator are considered erroneous.

РЕЗЮМЕ. Описан Oxyrrhexis zephyrus sp.n., принадлежащий к группе родов Polysphincta. Как и другие виды этой группы новый вид - эктопаразит пауков. Новый вид выеден был из наземноживущей Enoplognatha serratosignata (L. Koch, 1879) из Норвегии. Предложена новая комбинация Chablisea shaanxiensis (Liu, He et Chen, 2009) comb.n. ex. Oxyrrhexis. Таким образом, Oxyrrhexis включает всего 4 вида, но теперь с 2 видами в Западной Палеарктике. Oxyrrhexis carbonator (Gravenhorst, 1807), и его подвид texana (Cresson, 1870), впервые отмечены на Аляске. Steatoda bipunctata (Linnaeus, 1758 ) отмечена как хозяин $O$. carbonator in в Европе Europe. Судя по множеству выведенных особей из Финляндии, Швеции и Норвегии это единственных хозяин номинативного подвида, по крайней мере в северной Европе. Приведены фотографии пораженных хозяев и коконы нового вида и O. carbonator. Зарегистрированные виды хозяев рода Oxyrrhexis и другие приведённые данные указывают на то, что род специализирован к паразитированию на пауках семейства Theridiidae. Литературные указания хозяев $O$. carbonator из других семейств пауков и насекомых считаются ошибочными.

\section{Introduction}

The Polysphincta genus-group is a monophyletic linage of Pimplinae comprising 22 genera [Yu et al., 2012]. As far as is known, all species of the genusgroup are koinobiont ectoparasitoids of spiders, and this is a unique trait in Ichneumonidae. Oxyrrhexis Foerster, 1869, belonging to this genus-group, is a small Holarctic genus comprising only four species [Yu et al., 2012], half of which were recently described from China [Liu et al., 2009a]. The Holarctic Oxyrrhexis carbonator (Gravenhorst, 1807) has been reared from Steatoda borealis (Hentz, 1850) in North Ameri- 
ca [Townes \& Townes, 1960]. The hosts of the other species are still unknown.

The theridiid species Enoplognatha serratosignata (L. Koch, 1879) was recently unexpectedly discovered in Norway by the second author (unpubl.). A few of the collected specimens were later observed to be bearing a parasitoid larva in a transverse position anteriorly on the spider's opisthosoma. Since there are no literature records of Enoplognatha as hosts for any species of the Polysphincta genus-group [Yu et al., 2012] and the larval placement was unusual on a theridiid but similar to the one of $O$. carbonator on its theridiid host Steatoda bipunctata (Linnaeus, 1758) (Figs 1-2), we revisited the area in 2013 with the purpose of collecting more parasitised specimens for rearing.

The main aim of this paper is to describe an unknown Oxyrrhexis species reared from the spider E. serratosignata in Norway, to present its natural history and to discuss the host ranges of the genus Oxyrrhexis based largely on the extensive rearing data of the first author.

\section{Materials and methods}

The type and non-type specimens from institutional or other collections studied for the purpose of this paper are listed below each species. The two Chinese species described by Liu et al. [2009a] have only been studied through their original descriptions. Morphological terminology follows that of Gauld [1991]. The measurements were made using an ocular micrometer.

Figures 4-13 were made using a JEOL JSM-5200 scanning electron microscope or an Olympus E-520 DSLR attached to an Olympus SZX16 stereomicroscope and composed using CombineZM image stacking software at the Zoological Museum, University of Turku. The other close-ups were taken with Olympus E-3 DSLR with a twin flash.

Abbreviations used in the text: coc. refers to date of finishing the construction of the cocoon; em. to date of emergence. Explanations of some adjectives used in the description: smooth - without macro- or coarse microstructure; polished - shiny, even if there are structure and setae; glabrous - without setae.

Acronyms for depositories: NRF — private collection of the first author, FI; ZMUT - Zoological Museum, University of Turku, FI; MZH - Zoological Museum of University of Helsinki, FI; BMNH - The Natural History Museum, London, UK; NMS - National Museums of Scotland, Edinburgh, UK; ZISP Zoological Institute of the Russian Academy of Sciences, St. Petersburg, RU.

\section{Taxonomy}

\section{Oxyrrhexis Foerster, 1869}

Type species: Cryptus carbonator Gravenhorst, 1807 , by subsequent designation [Schmiedeknecht, 1888].
DIAGNOSIS. Small to medium sized and moderately stoutly built parasitoid wasps of the Polysphincta genus-group, with body length 3.3-7.9 mm, some species exhibiting great intraspecific size variation. Colouration except for legs mostly black. Occipital carina mediodorsally complete or interrupted. Palpal formula 5:4. Malar space 0.8-1.0x basal mandibular width. Mesoscutum with deeply impressed notauli, uniformly punctate and densely hirsute. Propodeum with strong or weakly developed carinae. Hindwing with distal abscissa of $C u 1$ present. Tergite I of metasoma not elongate (non-petiolate). Tergite II with anterolateral oblique grooves and centrally strongly to weakly biconvex. Tergite III-IV strongly to weakly biconvex with moderately coarse to shallow setiferous punctures. Ovipositor moderately short and stout, almost straight, awl-like, with only weak swellings, projecting beyond apex of metasoma by $0.27-0.47$ times length of hind tibia. For a more detailed diagnosis but based on only two species see Gauld \& Dubois [2006].

\section{Excluded species}

Chablisea shaanxiensis (Liu, He et Chen, 2009) comb.n.

Oxyrrhexis shaanxiensis described by Liu et al. [2009a] from China is excluded from Oxyrrhexis. It differs from the other species placed in Oxyrrhexis in its colourfulness, the slightly petiolate tergite I, tergite II centrally rhombically convex instead of biconvex. The head is also very different from that of Oxyrrhexis. The eyes reach close to the mandibles (malar space only $0.4 \mathrm{x}$ basal mandibular width). The shape of the face and clypeus in lateral view in combination with the low position of the head and the other characters mentioned above make it fit better in the genus Chablisea Gauld et Dubois, 2006 than in Oxyrrhexis. Chablisea is a small genus previously with 6 known species from China, Vietnam and Papua New Guinea [Gauld \& Dubois, 2006, Liu et al., 2009b, Pham et al., 2011]. There are no host records for Chablisea, but since it belongs in the Polysphincta genus-group it will presumably turn out to be spiders.

\section{Included species}

Oxyrrhexis carbonator (Gravenhorst, 1807) 1807)

Oxyrrhexis carbonator carbonator (Gravenhorst,

Figs 1-3, 11-13.

Synonyms (according to Yu et al. [2012]): O. carbonatrix (Schulz, 1906); O. pusilla (Fonscolombe, 1854); O. velata (Hartig, 1838); O. morio (Kiss, 1929); O. morio (Hellen, 1915).

MATERIAL EXAMINED: FINLAND: 27 우 $26 \sigma^{7} \sigma^{7}$ (NRF), from latitude $59^{\circ} 50^{\prime}$ in south, north to $65^{\circ} 01^{\prime}$, specimens collected during 2003-2013, 52 exx. ex Steatoda bipunctata, 1 exx. ex "black Araneae" (37 exx. N.R. Fritzén, 11 exx. I. Österblad, 2 exx. 

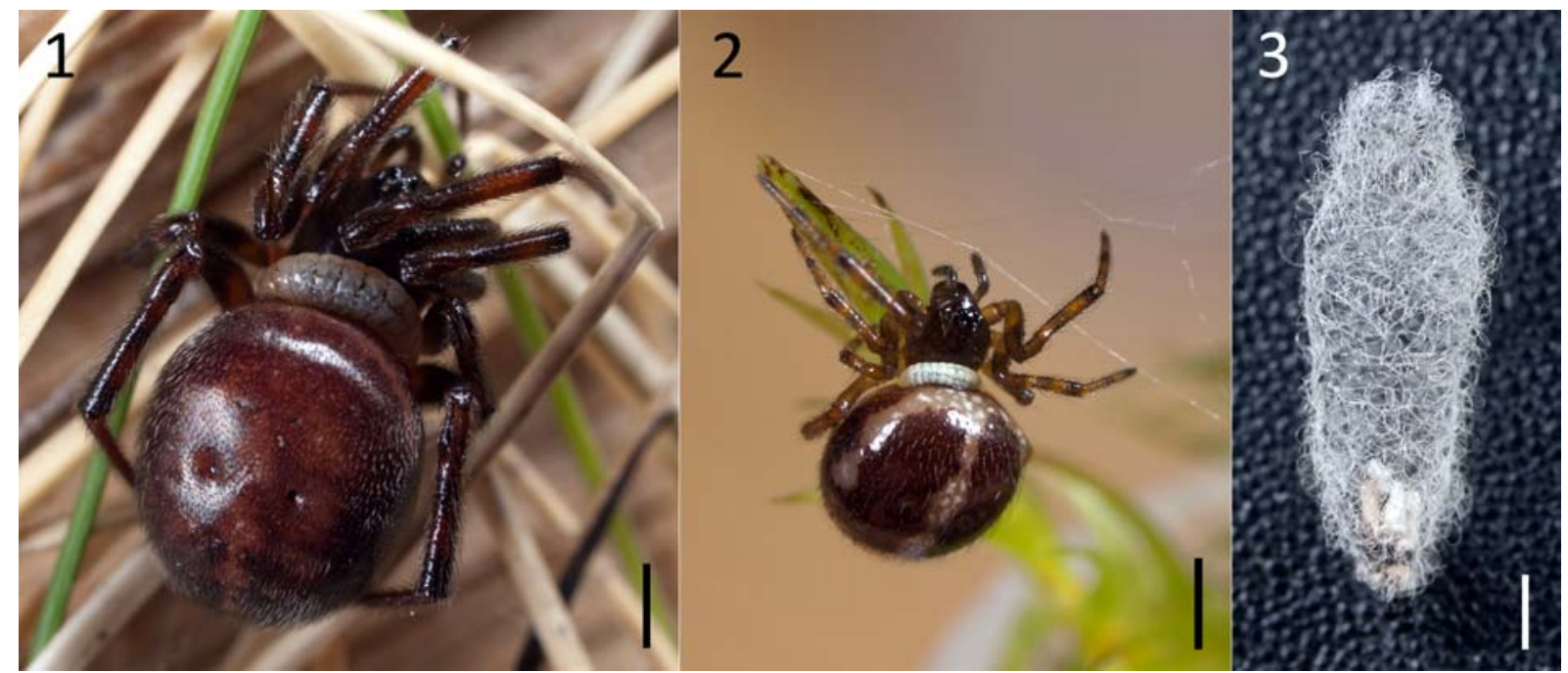

Figs 1-3. Early stages of Oxyrrhexis carbonator: 1 - larva on an adult female of Steatoda bipunctata, 2 - larva on a juvenile of the same species, 3 - cocoon. Scale bars $1 \mathrm{~mm}$.

Рис. 1-3. Ранние стадии Oxyrrhexis carbonator: 1 - личинка на самке Steatoda bipunctata; 2 - личинка на неполовозрелой особи того же вида; 3 - кокон. Масштаб 1 мм.

A. Kakko, 1 exx. T. Vainio, 1 exx. K. Kautonen, 1 exx. S. Väänänen); Polysphincta carbonator var. morio KISS 1929 Lectotype $0^{7}$ (MZH Spec. typ. No 5256), Kalajoki (Wuorentaus), P. carbonator ab. morio Hellén; SWEDEN: 1 (NRF), Kalix, Galberget, $66^{\circ} 06.3^{\prime} \mathrm{N}$ $22^{\circ} 54.4^{\prime} \mathrm{E}$, in cottage, ex S. bipunctata, 26.V.2008, coc. 3.VI.2008, em. VI.2008 (N.R. Fritzén); NORWAY: 1 † (NRF), Garmo, $61^{\circ} 51.18^{\prime} \mathrm{N} 08^{\circ} 43.46^{\prime} \mathrm{E}$, in rock crevice in pine forest on south slope, ex adult of S. bipunctata 1.V.2013, coc. 12.V.2013, em. 22.V.2013 (N.R. Fritzén).

\section{Oxyrrhexis carbonator texana (Cresson, 1870)}

Synonyms (according to Yu et al. [2012]): Oxyrrhexis bicarinata (Davis, 1898); Oxyrrhexis vicina (Provancher, 1873)

MATERIAL EXAMINED: USA: 1 (NRF), Alaska, Kenai NWR, Soldotna, Ski Hill Rd., $60.4646^{\circ} \mathrm{N} 151.0734^{\circ} \mathrm{W}$, ex Steatoda borealis(?), 2.II.2007, coc. 6.II.2007, em. 20.II.2007 (M.L. Bowser)

\section{Oxyrrhexis eurus Kasparyan, 1977}

Synonym: O. chinensis He, 1996 [Liu et al., 2009a]

MATERIAL EXAMINED: RUSSIA: Holotype + (ZISP), Kuril Isles, Kunashir Isl., Tretyakovo 5.8.1973 (Kasparyan). Paratypes (BMNH): 1 ㅇ, Kunashir Isl., Tretyakovo, 4.8 .1973 (Kasparyan); $1 \mathrm{O}^{7}$, Kunashir Isl., 1-10 km N of Dubovoye, 18.07.1973 (Kasparyan)

\section{Oxyrrhexis rugosa Liu, He et Chen, 2009}

No material examined. Still only known from the holotype female (China, Inner Mongolia, Zheng Xiang Bai Qi Plain).

\section{Oxyrrhexis zephyrus Fritzén sp.n.}

Figs 4-10, 14-16.

MATERIAL EXAMINED: NORWAY: Holotype + (ZMUT) Bismo, Skjåk, $61^{\circ} 53.11^{\prime} \mathrm{N} 08^{\circ} 16.67^{\prime} \mathrm{E}$, under stone/piece of wood at south facing sandy slope in open pine forest, ex subadult $\sigma^{7}$
Enoplognatha serratosignata 21.IV.2013, coc. 13.V.2013, em. 23.V.2013 (A. Fjellberg); Paratypes: 2 우, $1 O^{7}$ (1 9 in BMNH, 1 $\sigma^{7}$ in NMS, 1 in NRF), same site and coll. date as holotype, ex subadult E. serratosignata, coc. 30.IV-13.V.2013, em. 1724.V.2013 (A. Fjellberg); 1 ㅇ (NRF), same site as holotype, ex subadult $\mathrm{O}^{7}$ E. serratosignata, 1.V.2013, em. V.2013 (N.R. Fritzén);

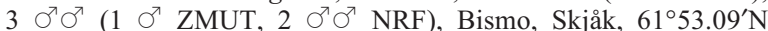
$08^{\circ} 16.92^{\prime} \mathrm{E}$, under stone/piece of wood at south facing sandy slope in open pine forest, ex subadult $O^{7}$ E. serratosignata 2.V.2013, em. 22-28.V.2013 (2 exx. N.R. Fritzén, 1 exx. A. Fjellberg); 2 오 (ZISP, ZMUT), Lom, Skim, $61^{\circ} 50.73^{\prime} \mathrm{N} 08^{\circ} 34.69^{\prime} \mathrm{E}$, under stones in open grass field on dry sandy ground, ex Enoplognatha serratosignata, and larva in cocoon in web of E. serratosignata, 20.VII.2013, em. 30.VII.2013 \& 2.VIII.2013 (A. Fjellberg).

DIAGNOSIS. The new species is morphologically distinctly different from the three other known species of the genus and may be separated from them by the combination of the following characters: (1) the mediodorsally interrupted occipital carina, (2) the subvertical wrinkles on the middle part of the lateral surface of the pronotum posterior to the epomia, (3) the short marginal cell of the fore wing with convex radius, and (4) the very stout and in both sexes black hind coxa. In addition the new species is characterised by its rather small size and stoutly built body, short antennae, the strong carinae of the propodeum and the coarsely and very densely punctured gastral tergites. Diagnostic features are listed and compared with its congeneric species in Table 1.

DESCRIPTION. Holotype ${ }_{+}$: body $4.6 \mathrm{~mm}$ long, length of fore wing $3.8 \mathrm{~mm}$.

Head. Malar space 0.9x basal mandibular width, without subocular sulcus but with band of coriaceous sculpture. Mandible more or less untwisted, abruptly narrowing with long fine apical part with straight and rather blunt teeth, upper one longer than lower one. Clypeus weakly separated from face by a shallow supraclypeal suture. Face $1.0 \mathrm{x}$ as wide as high, densely 

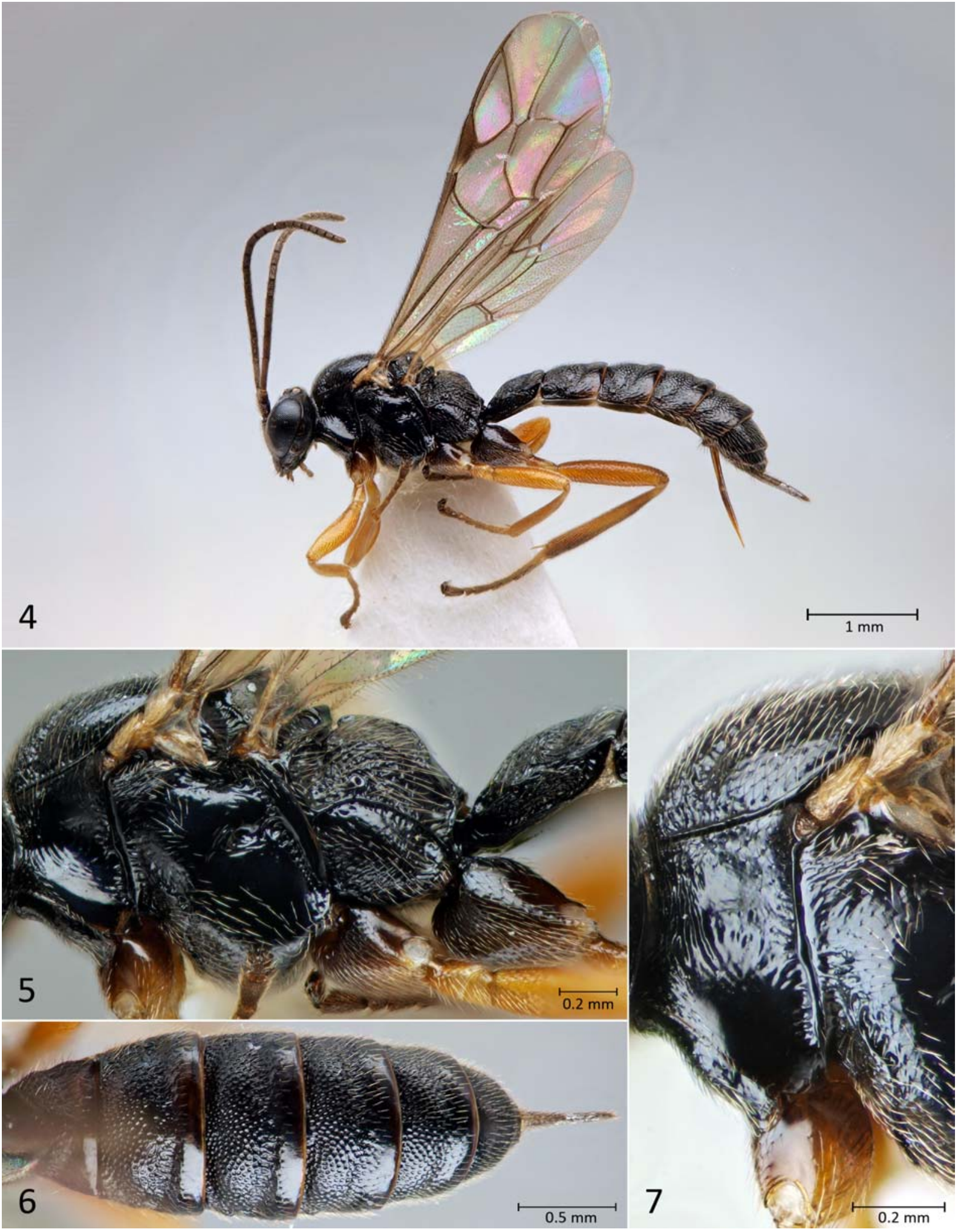

Figs 4-7. Holotype of Oxyrrhexis zephyrus sp.n.: 4 - habitus in lateral view, 5 - mesosoma in lateral view, 6 - metasomal tergites in dorsal view, 7 - close-up of the epicnemal carina and the vertical wrinkles on the lateral surface of the pronotum.

Рис. 4-7. Голотип Oxyrrhexis zephyrus sp.n.: 4 - габитус сбоку; 5 - мезосома сбоку; 6 - тергиты метасомы, сверху, 7 препектальный валик и вертикальные бороздки на боковой поверхности пронотума. 


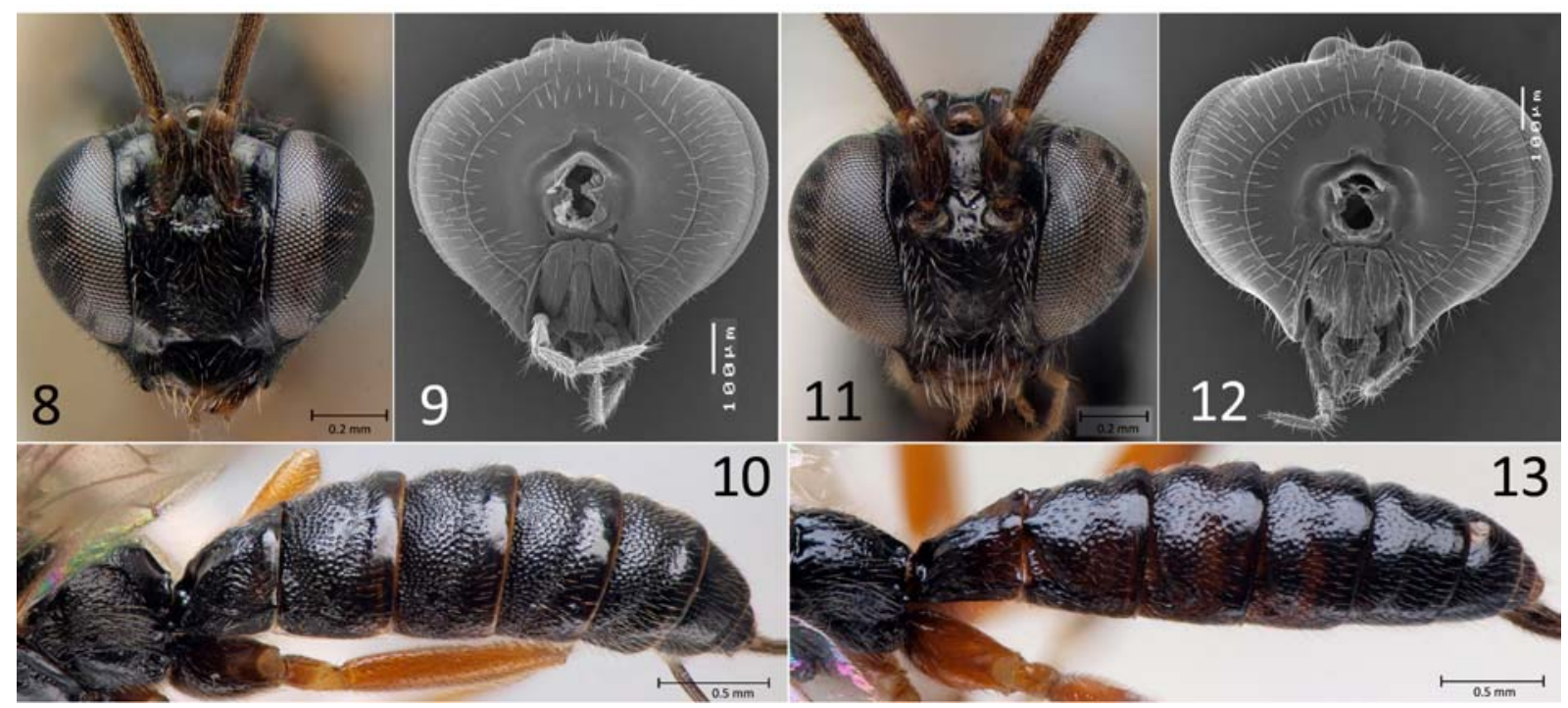

Figs 8-13. Oxyrrhexis zephyrus sp.n. (8-10) and $O$. carbonator (11-13): 8, 11 - head from in front; 9,12 - head in posterior view, showing the mediodorsally interrupted occipital carina (9) and complete occipital carina (12); 10, 13 - propodeum and metasomal tergites in dorsolateral view. 8,10 - holotype; 9 - paratype.

Рис. 8-13. Oxyrrhexis zephyrus sp.n. (8-10) и O. carbonator (11-13): 8, 11 - голова спереди; 9, 12 - голова сзади, показан разомкнутый (9) неразомкнутый (12) валик на затылке сверху; 10, 13 - проподеум и матасомальные тергиты голотипа, сверхусбоку. 8, 10 - голотип; 9 - паратип.

covered by setae, middle part from supraclypeal suture to antennal sockets slightly protruding. Surface of eyes with very sparse and short setae. Antenna with 19 flagellomeres, length-to-width ratio of first flagellomere 5.0, of second 3.0. Palpal formula 5:4. Head, in dorsal view, with gena weakly receding and weakly rounded; posterior ocellus separated from eye by $1.1 \mathrm{x}$ its own maximum diameter; gena, cheeks and frons hirsute; occipital carina present but mediodorsal part hidden between head and pronotum and not clearly seen.

Mesosoma. Pronotum laterally glabrous except for dorsal and anterior margins, more or less vertical bowshaped wrinkles medially, otherwise mostly smooth and polished; epomia at first more or less straight then slightly curving posteriad, reaching dorsal margin of (but not continuing across or along) pronotal collar. Mesoscutum subpolished but densely covered by setiferous shallow punctures; notauli moderately strong. Mesopleuron dorsally, ventrally and anteriorly pubescent, otherwise polished and mostly smooth; epicnemial carina extending dorsally beyond ventral corner of pronotum, its upper end turning anterodorsad, on its posterior side strong irregular pit-like rugosities. Mesosternum pubescent. Metapleuron convex, hirsute, ventrally and medially with weak rugosities; submetapleural carina strong and complete. Propodeum with large fused glabrous and mostly smooth area petiolaris, area postero-externa, area basalis and area superomedia, all fused to one area enclosed by strong carinae consisting of lateromedian carina joining laterlongitudinal carina via posterior transverse carina, propodeum otherwise rugulose with rather long coarse setae; pleural carina complete but anteriorly weak. Forewing with $2 r s-m$ short, about $2.5 \mathrm{x}$ as long as broad, marginal cell very short with second segment of radius turning slightly outwards, base of $1 \mathrm{~m}-\mathrm{cu}$ separated from $\mathrm{Cu}$ la by distance about twice length of $C u 1 \mathrm{~b}$. Hindwing with distal abscissa of $C u 1$ present, joining $c u$ - $a$ closer to $1 A$ than to $M$. Legs weakly specialised with fifth tarsomeres expanded and front femora incrassate. Hind coxa very stout, length about $1.2 \mathrm{x}$ its breadth. Length of hind femur $4.4 \mathrm{x}$ its breadth.

Metasoma. Tergite 1 of metasoma $0.9 x$ as long as posteriorly broad, laterally rugose/rugulose, with lateromedian carinae extending about $0.5 x$ length of segment; tergite $20.6 \mathrm{x}$ as long as posteriorly broad; central area of tergites 2-3 weakly biconvex, surrounded anteriorly, laterally and posteriorly by moderately deep broad grooves, the grooves and convex areas with dense coarse setiferous punctures. Ovipositor $0.75 \mathrm{x}$ as long as hind tibia, projecting beyond apex of metasoma by $0.38 \mathrm{x}$ length of hind tibia, almost straight, awl-like with no distinct swellings at base or middle, tapering from its apical 0.25 .

Colour. Body black. Antennae blackish brown. Apex of clypeus, mandibles (teeth blackish), palpi, tegula, ovipositor, thin posterior margin of tergites brownish. Legs brown with coxae blackish except for apical parts of front and middle coxae brownish, tarsomeres 2-5 and apical half of hind tibia blackish brown, hind femora dorsally and apical third darker brown. Wings hyaline, smoky; pterostigma brown with basal 0.2 uncoloured.

Paratype females: $4.3-4.8 \mathrm{~mm}$ long. Length of fore wing 3.5-4.0 mm. Flagellomeres 17-18. In some spec- 


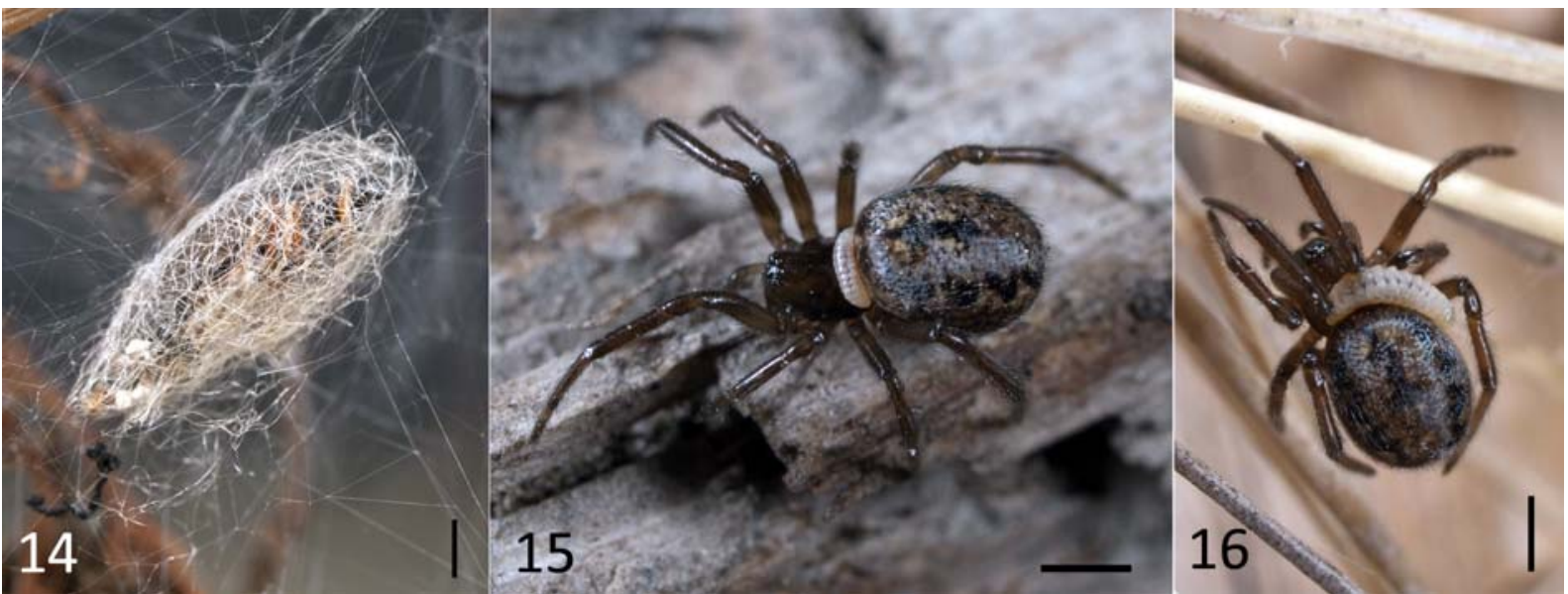

Figs 14-16. Oxyrrhexis zephyrus sp.n.: 14 - cocoon with paratype about to emerge, 15-16 - paratype larvae on Enoplognatha serratosignata in the typical transverse position anteriorly on the opisthosoma. Scale bars $1 \mathrm{~mm}$.

Рис. 14-16. Oxyrrhexis zephyrus sp.n:. 14 - кокон с паратипом, готовым к вылуплению, 15-16 - паратип личинки на Enoplognatha serratosignata в типичном, положении спереди поперёк брюшка. Масштаб 1 мм.

imens $2 r s-m$ of fore wing slightly longer than in holotype. The median subvertical wrinkles of the lateral surface of pronotum varies somewhat, in one specimen there is only a single distinct wrinkle posterior of the epomia. Otherwise similar to the holotype. The distal abscissa of $C u 1$ of hind wing joins $\mathrm{cu}-\mathrm{a}$ more or less equidistantly between $M$ and $1 A$ in one specimen.

Paratype males: $4.4-5.1 \mathrm{~mm}$ long. Length of fore wing $3.7-4.0 \mathrm{~mm}$. Flagellomeres $17-19$. The distal abscissa of $C u 1$ of hind wing weak and joins $c u$ - $a$ more or less equidistantly between $M$ and $1 A$ in one specimen. Otherwise similar to the females.

In six paratypes the occipital carina is clearly visible and distinctly interrupted (Fig. 9).

TYPE LOCALITY (Figs 17-18). A sandy south facing slope with stones in open pine forest at the foot of Bispberget mountain in Bismo, Skjåk, 61 ${ }^{\circ} 53.11^{\prime} \mathrm{N}$ $08^{\circ} 16.67^{\prime} \mathrm{E}$, in the westernmost part of the Ottadalen river valley in Oppdal county in Norway, altitude about $450 \mathrm{~m}$. Due to rain shadow, the deep valleys in this area are among the most arid places in Europe (mean annual precipitation less than $300 \mathrm{~mm}$ ).

DISTRIBUTION. So far only known from Skjåk and Lom in Oppland county, Norway (see type material above).

ETYMOLOGY. In Greek mythology Zephyrus (Zephyros) is the god of the west wind, one of the four directional wind gods. Its counterpart Eurus is the god of the east wind (cf. the East Palaearctic Oxyrrhexis eurus).

BIOLOGICAL NOTES. The new species is a koinobiont ectoparasitoid of the theridiid spider Enoplognatha serratosignata. All specimens of the type series were found as larvae on E. serratosignata $(\mathrm{n}=9)$ or as cocoons in the web of this spider $(n=1)$. It overwinters as a small larva on mainly subadult spiders, presumably under stones and other objects where spiders bearing the larva have been observed in early September and at the end of April. In summertime, based on circumstantial evidence, it apparently attacks also adult hosts. At the type locality O. zephyrus sp.n. is at least bivoltine. Based on the rearing data the flight period is estimated to be from the end of May or early June with another generation from the turn of July/August. The larva is in a transverse position at the anterior apex of the opisthosoma, above the pedicel (Figs 15-16), in a similar position as seen in O. carbonator (Figs 1-2). The cocoon resembles that of $O$. carbonator, broadly spindle shaped, springy with loosely woven whorls of a light brownish colour (Fig. 14), but more irregularly woven and with less erect loops of silk than in $O$. carbonator. One cocoon with unpupated larva was found in the field under a stone with the host remains, small spiderlings and several egg sacs in the web of the host. Also based on the reared specimens, the cocoon is built in the web of the host and is not protected by any dense or otherwise distinctly modified silk structure made by the host. In the wild it is thus probably sufficiently sheltered by stones etc., where the host makes its webs.

\section{Discussion}

According to Yu et al. [2012], O. carbonator has 5 synonyms in Europe. The types of two of the three heterotypic synonyms of $O$. carbonator has been examined, one of them based on photographs. The original description of Polysphincta velata Hartig, 1838 is very brief and according to it, $P$. velata develops as a parasitoid of the larva of the geometrid moth Bupalus piniaria (Linnaeus, 1758) [Hartig, 1838]. Apparently on the basis of the supposed host, and without seeing the type specimen, Schmiedeknecht [1934] was of the opinion that $P$. velata is definitely not a "Polysphinc$t a$ ". Based on its non-spider host and that such a rearing has never been repeated, we couldn't but agree, but 
Table 1. Diagnostic features of Oxyrrhexis zephyrus sp.n. compared to its three congeneric species, with notes on the distribution and hosts of the species.

Табл. 1. Отличительные признаки Oxyrrhexis zephyrus sp.n. в сравнении с другими видами рода, с замечаниями по распространению и видам-хозяевам.

\begin{tabular}{|c|c|c|c|c|}
\hline Feature & $\begin{array}{l}\text { O. zephyrus } \\
\text { sp.n. }\end{array}$ & $\begin{array}{c}\text { O. eurus } \\
\text { Kasparyan, } 1977\end{array}$ & $\begin{array}{c}\text { O. carbonator } \\
\text { (Gravenhorst, 1807) }\end{array}$ & $\begin{array}{l}\text { O. rugosa Liu, He et } \\
\text { Chen, 2009* }\end{array}$ \\
\hline Occipital carina & dorsally interrupted & $\begin{array}{c}\text { dorsally } \\
\text { interrupted }\end{array}$ & complete & complete \\
\hline $\begin{array}{l}\text { Lateral surface } \\
\text { of the pronotum }\end{array}$ & with wrinkles & smooth & smooth & with wrinkles \\
\hline $\begin{array}{l}\text { Marginal cell } \\
\text { (radial cell) }\end{array}$ & $\begin{array}{l}\text { very short with } \\
\text { radius slightly } \\
\text { convex }\end{array}$ & $\begin{array}{l}\text { short with radius } \\
\text { slightly convex }\end{array}$ & long with radius concave & $\begin{array}{l}\text { long with radius } \\
\text { concave }\end{array}$ \\
\hline $\begin{array}{l}\text { Distal abscissa } \\
\text { of } C u 1 \text { of hind } \\
\text { wing }\end{array}$ & $\begin{array}{c}\text { joining } c u \text { - } a \text { usually } \\
\text { distinctly closer to } \\
1 A \text { than to } M\end{array}$ & $\begin{array}{l}\text { joining } c u-a \\
\text { closer to } 1 A \text { than } \\
\text { to } M\end{array}$ & $\begin{array}{c}\text { joining } \mathrm{cu} \text { - } a \text { usually equidistantly } \\
\text { between } M \text { and } 1 A\end{array}$ & $\begin{array}{c}\text { joining } c u-a \\
\text { equidistantly between } \\
M \text { and } 1 A\end{array}$ \\
\hline $\begin{array}{l}\text { Flagellomeres } \\
\text { o/ }+0^{7}\end{array}$ & $17-19 / 17-19$ & $\begin{array}{l}20-22 / 20 \\
(18-22)^{* *}\end{array}$ & $22-24(27 * * * *) / 19-22$ & $23 / ?$ \\
\hline Hind coxa & $\begin{array}{l}\text { black in both sexes } \\
\text { and very stout }\end{array}$ & $\begin{array}{c}\text { reddish, not } \\
\text { particularly stout }\end{array}$ & $\begin{array}{l}\text { usually reddish-brown in } 9 \text { and } \\
\text { blackish-brown in } \bigcirc^{7} \text {, but any variation } \\
\text { on this occurs, not particularly stout }\end{array}$ & $\begin{array}{l}\text { reddish brown, not } \\
\text { particularly stout }\end{array}$ \\
\hline $\begin{array}{l}\text { Length of body } \\
(\mathrm{mm})+/ \sigma^{7}\end{array}$ & $4.3-4.8 / 4.4-5.1$ & $6.0 * * *$ & $5.2-7.9 / 3.3-5.5$ & 7.0 \\
\hline $\begin{array}{l}\text { Length of fore } \\
\text { wing }(\mathrm{mm})+/ \bigcirc^{7}\end{array}$ & $3.5-4.0 / 3.7-4.0$ & $3-5.2 * *$ & $4.4-6.4 / 2.7-4.3$ & 6.0 \\
\hline Hosts & $\begin{array}{l}\text { Enoplognatha } \\
\text { serratosignata }\end{array}$ & unknown & Steatoda bipunctata and $S$. borealis & unknown \\
\hline $\begin{array}{l}\text { Known } \\
\text { distribution }\end{array}$ & Norway & $\begin{array}{c}\text { East Palaearctic: } \\
\text { China, Mongolia, } \\
\text { Russia }\end{array}$ & Holarctic & $\begin{array}{l}\text { China (Inner } \\
\text { Mongolia) }\end{array}$ \\
\hline
\end{tabular}

*only known from holotype + ; **Kasparyan [1977], sexes not given separately; ***based on holotype only; $* * * *$ in the single $O$. carbonator texana examined.

* известен только по голотипу (†); ** Каспарян [1977], самцы и самки приведены вместе; *** основано на изучении только голотипа; **** исследован только один экземпляр O. carbonator texana.

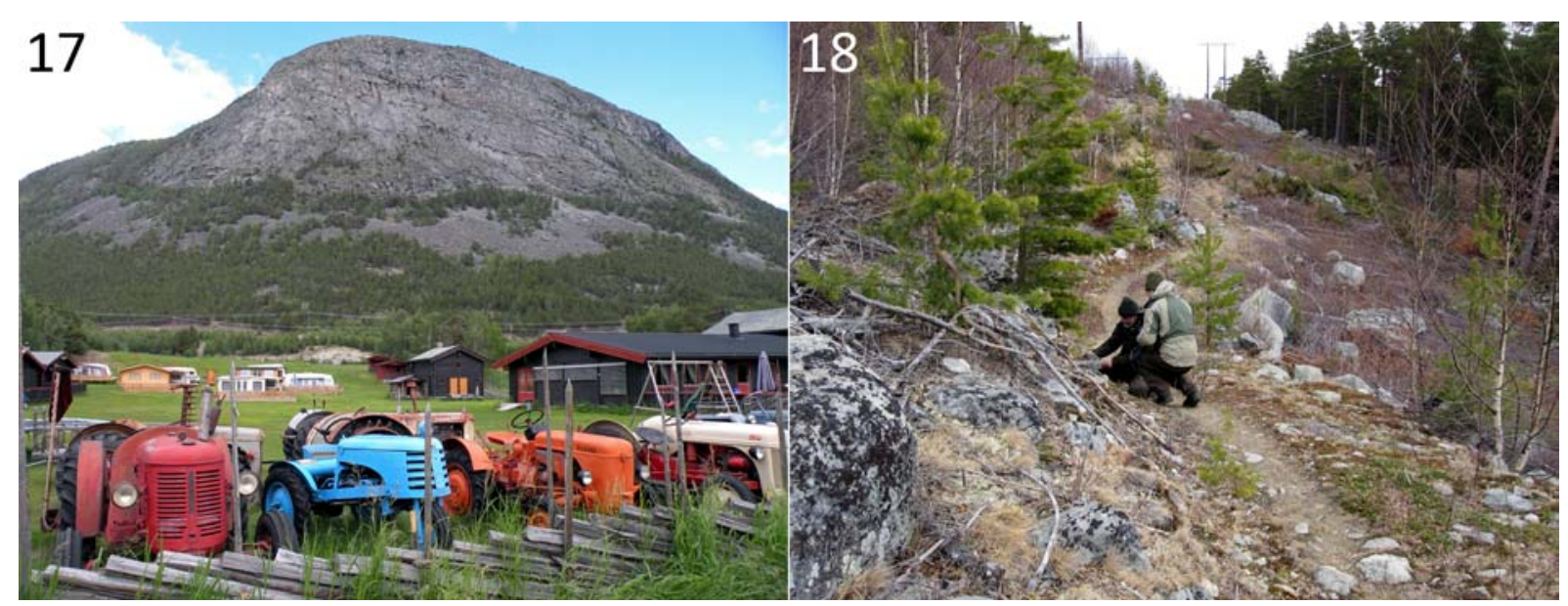

Figs 17-18. Type locality of Oxyrrhexis zephyrus sp.n.: 17 - the foot of Bispberget mountain (background) at Bismo in Skjåk, Norway, 18 - the authors looking for parasitised specimens of Enoplognatha serratosignata under stones.

Рис. 17-18. Типовое местобитание Oxyrrhexis zephyrus sp.n.: 17 - подножье горы Bispberget (на заднем плане) в Bismo, коммуна Skjek, Норвегия, 18 - авторы ищут зараженные особи Enoplognatha serratosignata под камнями. 
after examining the type from photographs it is evident that it fits the description well and is correctly synonymised. There is a cocoon pinned with the specimen but no accompanying host remains. Thus we presume that the true host was not recognised, for example perhaps a parasitised spider found its way into the rearing cage, or a cocoon of the Oxyrrhexis was collected simultaneously and overlooked - the kinds of occurrence that underlie many spurious host records in the literature [Shaw, 1994]. The type labelled "Polysphincta velata Th.Hartig det." indicates that this is the specimen he referred to when describing the taxon.

The description of Polysphincta pusilla Fonscolombe, 1854, based on a single male specimen, gives no reason to believe that it could represent a specimen of the new species. According to the original description [Fonscolombe, 1854], it differs from O. carbonator only in its small size and its blackish hind coxa. The size variation in $O$. carbonator is wide, with some very minute males (body length of $3.3 \mathrm{~mm}$ in our study). In addition, according to Hellén [1915] and Šedivý [1963], and also based on the material examined in this paper, the colour of the coxae in O. carbonator varies greatly and especially in males the hind coxa is often blackish. Based on this character in Finnish specimens, Hellén [1915] named a colour aberration "morio". This colour form was, due to subsequent nomenclatorial rules, probably unintentially raised to subspecies level by Kiss [1929], by referring to it as "var. morio Hellen, 1915" when, for the first time, recording it from Hungary. O. morio (Kiss, 1929) has later been synonymised with $O$. carbonator by Horstmann [2009]. Finally, the name Acrodactyla carbonatrix Schulz, 1906 is an unjustified emendation and a junior objective synonym for $O$. carbonator. Thus, there is no indication that any of the synonyms of $O$. carbonator could represent the new species.

The Nearctic subspecies $O$. carbonator texana, occurring from Canada (except the three northern territories) throughout the USA south to Texas [Yu et al., 2012], differs from the nominate subspecies mainly based on leg colouration [Townes \& Townes, 1960]. The single Nearctic specimen examined by us, which is the northernmost Nearctic record and the first record of the species for Alaska [Townes \& Townes, 1960; Yu et al., 2012], also has more antennal flagellomeres than similar-sized specimens from northern Europe (see Table 1). The synonyms of the Nearctic subspecies have not been taken into account in this part of the discussion.

In the original description of O. eurus [Kasparyan, 1977], it is not mentioned whether the occipital carina is complete or dorsally interrupted. Nor is it mentioned in Liu et al. [2009a] in their redescription of O. eurus, which was partly based on specimens of the type series of $O$. chinensis. In the diagnosis of Oxyrrhexis in Gauld \& Dubois [2006] it is stated that the occipital carina is complete in this genus. However, in the matrix in the same paper $O$. eurus is coded as having a dorsally interrupted occipital carina. The examination of the holotype and two paratypes of $O$. eurus revealed that they all have a dorsally interrupted occipital carina. As far as is now known, the occipital carina is complete in two species of Oxyrrhexis and dorsally interrupted in two (see Table 1 ). Since $O$. chinensis was synonymised with $O$. eurus without comparing it with type specimens of $O$. eurus, and the ovipositors seem to be of different length (at least compared to the length of the second tergite), it would be worth checking the occipital carina in the types of $O$. chinensis, since it is a character which could support or refute the synonymy.

The spider parasitoids of the Polysphincta genusgroup are both biologically and morphologically among the most specialised of Pimplinae and in general have narrow host ranges [Fitton et al., 1988; Shaw, 1994]. As a rule, but with exceptions, one parasitoid wasp genus of the Polysphincta genus-group is restricted to hosts of one spider family [Shaw, 1994]. The members of the genus Zatypota Foerster, 1869 are the most well known parasitoids that attack spiders belonging to the family Theridiidae [Shaw, 1994; Matsumoto \& Takasuka, 2010; Fritzén, 2010]. However, Zatypota is mainly restricted to hosts of the subfamily Theridiinae, whereas the hosts of Oxyrrhexis are in Asageninae and Enoplognathinae, the latter two considered closely related by some authors [e.g. Wunderlich, 2008].

In both $O$. carbonator and $O$. zephyrus sp.n. the young larva is in a transverse position at the anterior apex of the host's opisthosoma, just above the pedicel. The posterior end of the larva is attached to one side of the pedicel and the anterior part of the larva grows laterally on the opposite side of the pedicel, towards the posterior part of the opisthosoma. In Zatypota, larval placement varies; it is sometimes anteriorly on the host's opisthosoma, but it is rarely in the transverse position growing from one side of the pedicel to the other as in Oxyrrhexis. This position is, however, common for the larva of species of the genus Polysphincta, but in this case on different hosts (Araneidae).

Based on the generally narrow host ranges of the species of the Polysphincta genus-group and the rearing data presented in the present paper, we consider it unlikely that the new species also parasitises e.g. Enoplognatha ovata (Clerck, 1757), a species which is common throughout most parts of Europe. Compared to $E$. serratosignata, E. ovata is a rather long-legged species which lives in the vegetation well above ground-level. The rather short legs and stout body of $O$. zephyrus sp.n. are probably adaptations to ground-living and to the search for hosts in more concealed places than freely in the vegetation. However, we consider it possible that the new species will be found on other groundliving short-legged species of Enoplognatha (e.g. E. thoracica (Hahn, 1833), E. mordax (Thorell, 1875), E. oelandica (Thorell, 1875)). Therefore we encourage people to look for parasitised specimens of these, particularly in warm and sunny sites where the spiders are locally frequent, like E. serratosignata is at the type locality of $O$. zephyrus sp.n. 
The literature includes a wide range of purported hosts for $O$. carbonator, including species of Theridiidae, Linyphiidae, Araneidae, Tetragnathidae and Thomisidae [Shaw, 1994; Gauld \& Dubois, 2006]. This also becomes evident in Yu et al. [2012], who additionally list several non-spider hosts for $O$. carbonator. According to Shaw [1994], this seemingly broad host range is at least partly due to the fact that the name "Polysphincta carbonator Gravenhorst" was in early literature misapplied to almost any species of the Polysphincta genus-group. From the Nearctic there are some records of $O$. carbonator ssp. texana reared from Steatoda borealis that seem reliable (including the record in this paper, although the collector chose to add a "?" to the host species' name).

In $\mathrm{Yu}$ et al. [2012] there are no records of any Steatoda species as host for $O$. carbonator from Europe. While preparing our paper it became evident that there are, in fact, no published reliable records of any host species from Europe. However, Gauld \& Dubois [2006], by referring to Aubert [1969] and Shaw [1994], mentions Steatoda spp. records also from Europe. Aubert [1969] lists among many non-Steatoda hosts only $S$. borealis, and by this without doubt referring to Nearctic records as $S$. borealis is not a European species. In Shaw [1994] no host species is named, only Stetatoda spp. at the genus level for both literature records and four rearing records within his polysphinctine project that covered European species. Mark Shaw has informed us what these records were based on, and has kindly provided us with the data of the reared specimens. The literature records in Shaw [1994] were of the Nearctic $S$. borealis, and the other records referred to four specimens of $O$. carbonator reared from $S$. bipunctata in southern Sweden, all with the same data as follows: Sweden, Småland, Massemåla, near Högsby, ex S. bipunctata, collected (on host) X.1987 em. XI.1987 (I.H.S. Clausen). These specimens (in the National Museums of Scotland) seem to be the only previous (but unpublished) host records for Palaearctic $O$. carbonator. Steatoda bipunctata in our paper as host for $O$. carbonator are consequently the first published ones from the Palaearctic. All previous host records in the literature of non-Steatoda spiders listed by $\mathrm{Yu}$ et al. [2012] (Araneus diadematus Clerck, 1757, Gibbaranea bituberculata (Walckenaer, 1802), Araniella cucurbitina (Clerck, 1757), Lepthyphantes minutus (Blackwall, 1833), Metellina merianae (Scopoli, 1763), Microlinyphia pusilla (Sundevall, 1830), Ebrechtella tricuspidata (Fabricius, 1775)) or non-spiders (Lepidoptera: Bupalus piniaria; Hymenoptera: Heterarthrus microcephalus (Klug, 1818); Coleoptera: Saperda populnea (Linnaeus, 1758)), we consider misidentifications of either the parasitoid or the host.

The host of $O$. zephyrus sp.n. is very intriguing. Together with the host records of $O$. carbonator from the Nearctic and the large rearing material in this paper of $O$. carbonator exclusively from $S$. bipunctata $(\mathrm{n}=$ 58), it strongly supports the hypothesis that Oxyrrhexis is a genus specialised on theridiid hosts and that it might be restricted to only a part of this spider family. Therefore we expect the other species of Oxyrrhexis, with still unknown hosts, to be found on species of Steatoda or Enoplognatha or on other genera within Asageninae and Enoplognathinae, but less likely on members of Theridiinae. The larva will probably be in a similar position as in the two species with now known hosts.

Enoplognatha serratosignata has a wide boreomontane distribution across the Palaearctic from Central Europe (Switzerland, Germany, Czech Republic, Slovakia, Hungary) [van Helsdingen, 2013] north to Norway (our study), east to Chukotka in the Russian Far East and south to Mongolia [Marusik et al., 2000]. It is surprising to find an undescribed parasitoid in a country where the host species is at the northwestern limit of its distribution in a seemingly isolated population. This further indicates [see Fritzén, 2010] that there are still unknown parasitoid wasp species in the Polysphincta genus-group out there, even in well studied areas, waiting to be collected by arachnologists as larvae on the backs of spiders, more easily than as adults collected in traditional ways such as in Malaise traps or by sweep netting.

ACKNOWLEDGEMENTS. We want to thank Stefan Schmidt (Munich) for providing us with photographs of the type of Polysphincta velata, and Andrei Humala (Petrozavodsk) for checking this specimen in situ for us. We also wish to thank Pekka Malinen (Helsinki), Dicky Yu (Ottawa), Alexey Reshikov (Stockholm), Vasilisa Chemyrova (St. Petersburg), Gavin Broad (London) and Yuri Marusik (Magadan) for help with literature and other information. Special thanks to Ritva Penttinen (Turku) for making the SEM figures and Mark Shaw (Edinburgh) and Ilari Sääksjärvi (Turku) for valuable comments on the manuscript.

\section{References}

Aubert J. 1969. Les Ichneumonides ouest-palearctiques et leurs hotes 1. Pimplinae, Xoridinae, Acaenitinae. Paris: Laboratoire d'Evolution des Etres Organises. 302 pp.

Fitton M.G., Shaw M., Gauld I.D. 1988. Pimpline Ichneumon-flies. Hymenoptera, Ichneumonidae (Pimplinae) // Handbook for the Identification of British Insects. Vol.7. P.1-110.

Fonscolombe M.B. de 1854. Ichneumonologie provençale ou catalogue des Ichneumonides qui se trouvent aux environs d'Aix, et description des espèces inédites // Annales de la Société Entomologique de France. Sér.3. T.2. P.497-520.

Fritzén N.R. 2010. Natural history and description of Zatypota kerstinae sp.nov. (Hymenoptera: Ichneumonidae) reared from Theridion palmgreni Marusik et Tsellarius (Araneae: Theridiidae) in Finland // Zootaxa. No.2487. P.52-60.

Gauld I.D. 1991. The Ichneumonidae of Costa Rica, 1 // Memoirs of the American Entomological Institute. Vol.47. P.1-589.

Gauld I.D., Dubois J. 2006. Phylogeny of the Polysphincta group of genera (Hymenoptera: Ichneumonidae; Pimplinae), a taxonomic revision of spider ectoparasitoids // Systematic Entomology. Vol.31. P.529-564.

Hartig T. 1838. Über den Raupenfrass im Königl. Charlottenburger Forste unfern Berlin, während des Sommers 1837 // Jahresber. Fortschr. Forstwiss. Forstl. Naturk. Berlin. Bd.1. S.246-274. 
Hellén W. 1915. Beiträge zur Kenntnis der Ichneumoniden Finlands I. Subfamily Pimplinae // Acta Societatis pro Fauna et Flora Fennica. Vol.40. No.6. S.1-89.

Helsdingen P.J. van, 2013. Araneae. In: Fauna Europaea Database (Version 2013.1), online at http://www.european-arachnology.org

Horstmann K. 2009. Typenrevisionen der von Kiss beschriebenen Taxa der Ichneumonidae III. Verschiedene Unterfamilien (Hymenoptera, Ichneumonidae) // Linzer biol. Beitr. Bd.41. H.1. S.673-689.

Kasparyan D.R. 1977. [Ichneumonids of the subfamilies Pimplinae and Tryphoninae (Hymenoptera Ichneumonidae) new for Mongolia and Transbaikalia.] // Nasekomye Mongolii [Insects of Mongolia]. T.5. P.456-469 [in Russian].

Kiss von Zilah A. 1929. Dritter Beitrag zur Kenntnis der un garischen und siebenbürgischen Ichneumoniden-(Schlupfwespen-) Fauna // Verhandlungen und Mitteilungen des Siebenburgischen Vereins für Naturwissenschaften in Hermannstadt. Bd.79/80. S.89-144.

Liu J.-X., He J.-H., Chen X.-X. 2009. Revision of genus Oxyrrhexis Foerster, 1869 (Hymenoptera: Ichneumonidae: Pimplinae) from China // Annales Zoologici. Vol.50. No.2. P.171-177.

Liu J.-X., He J.-H., Chen X.-X. 2009b. The two new species of genus Chablisea Gauld et Dubois, 2006 (Hymenoptera: Ichneumonidae: Pimplinae) from China// Biologia. Vol.64. No.6. P.1165-1169.

Marusik Y.M., Logunov D.V., Koponen S. 2000. Spiders of Tuva, south Siberia. Magadan: Institute for Biological Problems of the North. 253 pp.

Matsumoto R., Takasuka K. 2010. A revision of the genus Zatypota Förster of Japan, with descriptions of nine new species and notes on their hosts (Hymenoptera: Ichneumonidae: Pimplinae) // Zootaxa. No.2522. P.1-43.

Pham N.T., Broad G.R., Matsumoto R., Wägele W.J. 2011. Two new species of the genus Chablisea Gauld et Dubois (Hymenoptera: Ichneumonidae: Pimplinae) from Vietnam // Biologia. Vol.66. No.6. P.1134-1139.

Schmiedeknecht O. 1888. Die europäischen Gattungen der Schlupfwespen Familie Pimplariae // Zoologische Jahrbücher, Abteilung für Systematik. Bd.3. S.419-444.

Schmiedeknecht O. 1934. Opuscula Ichneumonologica. Supplement-Band. Neubearbeitungen. Fasc.21. Blankenburg in Thüringen. S.47-48, 1-30, 1-48.

Šedivý J. 1963. Die europäischen Arten der Gattungen Laufeia Tosq., Polysphincta Grav. und Zatypota Foerst. (Hym. Ichneumonidae) // Acta Faunistica Entomologica Musei Nationalis Pragae. Vol.35. P.243-261.

Shaw M.R. 1994. Parasitoid host ranges // Hawkins B.A., Sheehan W. (eds.). Parasitoid community ecology. Oxford: Oxford University Press. P.111-144.

Townes H.K., Townes M. 1960. Ichneumon-flies of America north of Mexico: 2 subfamilies Ephialtinae, Xoridinae, Acaenitinae // Bulletin of the United States National Museum. No.216. P.1676.

Yu D.S., van Achterberg C., Horstmann K. 2012. Taxapad 2012. Ichneumonoidea 2011. Taxonomy, biology, morphology and distribution, online at http://www.taxapad.com

Wunderlich J. 2008. On extant and fossil (Eocene) European combfooted spiders (Araneae: Theridiidae), with notes on their subfamilies, and with descriptions of new taxa // Beiträge zur Araneologie. Bd.5. P.140-469.

Responsible editor Yuri M. Marusik 